Original Article

\title{
PROTEIN BINDING STUDY OF FELODIPINE USING VALIDATED LIQUID CHROMATOGRAPHIC METHOD
}

\author{
SWARNA VIJITHA*, P. RAJAVEL, K. UDAYASREE \\ Department of Pharmaceutical Analysis, Sree Vidyanikethan College of Pharmacy, Sree Sainath Nagar, Chandragiri (Mandal), Tirupati, \\ Chittoor (Dist), A. P. \\ Email: vijitha.mayu@gmail.com
}

Received: 22 May 2017, Revised and Accepted: 22 Jul 2017

\begin{abstract}
Objective: The aim of present study was to develop and validate a new simple, easy, selective, precise, accurate reverse phase high-performance liquid chromatography for the estimation of felodipine in bulk and pharmaceutical dosage form.

Methods: The separation was carried on HPLC system consisting $C_{18}$ column $(150 \mathrm{~mm} \times 4.6 \mathrm{~nm}, 5 \mu \mathrm{m})$ at room temperature coupled with a phenomenixcolumn silica with flow rate $1 \mathrm{ml} / \mathrm{min}$. The mobile phase used was methanol: acetonitrile in the ratio of 50: 50. The drug was detected using UV-visible detector at the wavelength of $230 \mathrm{~nm}$ and run time was $10 \mathrm{~min}$.

Results: The retention time was 3.138 min. Linearity was observed in the concentration range of $5-25 \mu \mathrm{g} / \mathrm{ml}$. The accuracy of the method was assessed by percentage recovery studies at three different levels at $80 \%, 100 \%$ and $120 \%$ of its working concentration. The percentage recovery of felodipine in the developed method was found to be in the ranges of from $99.81-100.00 \%$ that indicates the good accuracy of the method. The percentage \% RSD of precision was found to be less than $2 \%$. The method was validated as per ICH guidelines. The developed method was employed in in vitro protein binding studies using semi permeable membrane and performed by plotting calibration curve (peak area $\mathrm{v}_{\mathrm{s}}$ concentration) the $\%$ drug release of felodipine was calculated.
\end{abstract}

Conclusion: The proposed method was found to be simple, precise, accurate and consistent. The validated parameters are statistically validated for linearity, precision and limit of detection, limit of quantification, robustness, ruggedness were concluded.

Keywords: Felodipine, RP-HPLC, ICH guidelines, \%RSD

(c) 2017 The Authors. Published by Innovare Academic Sciences Pvt Ltd. This is an open access article under the CC BY license (http://creativecommons.org/licenses/by/4.0/) DOI: http://dx.doi.org/10.22159/ijcpr.2017v9i5.22157

\section{INTRODUCTION}

Felodipine is a second-generation calcium channel blocker and commonly used antihypertensive agent. Felodipine belongs to the dihydropyridine group of calcium channel blocker (with amlodipine, isradipine, and nifedipine) and is used primarily in the therapy of hypertension. Like other calcium channel blockers, felodipine acts by blocking the influx of calcium ions into the vascular smooth muscle of voltage-gated sensitive channel cells by relaxing L-type calcium channel in their inactive conformation. By preventing the influx of calcium in smooth muscle cells. Felodipine chemically, ethyl methyl4(2, 3-chlorophenyl)-1, 4-dihydro-2, 6-dimethyl-5methyl ester, is a calcium agonist widely used in the treatment of hypertension, heart failure, and angina pectoris.

The molecular of felodipine is $\mathrm{C}_{18} \mathrm{H}_{19} \mathrm{C}_{12} \mathrm{NO}_{4}$ and molecular weight $384.254 \mathrm{~g} / \mathrm{mol}$. It is a white or light yellow, crystalline powder, practically insoluble in water, freely soluble in acetone, acetonitrile, ethanol, methanol, with melting point $145^{\circ} \mathrm{C}$ [1]. Felodipine is also used to treat mild to moderate critical hypertension [3]. Felodipinestructure was shown in fig. 1.

In literature, very few RP-HPLC [4-8], UV-Spectrophotometric [9] and HPTLC [10], methods have been reported for determination of felodipine in bulk drugs and pharmaceutical formulations and also in combination with other drugs. Hence an attempt has been made to develop a new assay method with less retention time for protein binding study of felodipine.

\section{MATERIALS AND METHODS}

\section{Chemicals and reagents}

Felodipine gift sample was procured from Madras pharmaceutical private limited. The com mercial tablet dosage form was obtained from local market labelled felogard (5 mg felodipine). HPLC methanol, acetonitrile and water were obtained from MerckspecialtiesPvt. Chennai, India. All the chemicals and reagents were analytical grade.

\section{HPLC instruments and chromatographic conditions}

The RP-HPLC method development and partial validation studies are performed using Shimadzu SPD 20ALC20Asystem. The column used for separation of the analyte is a phenomenex $\mathrm{C}_{18}$ column $(150 \mathrm{~mm}$ $\times 4.6 \mathrm{~mm} 5 \mu \mathrm{m}$ ) isocratic elution with methanol: acetonitrile as mobile phase (50:50). The sample was injected through Rhenodyne injector mode. The data was analyzed and saved in spinochrome software. The flow rate of the mobile phase is $1.0 \mathrm{ml} / \mathrm{min}$.

\section{Preparation of mobile phase}

The mobile phase was a mixture of methanol: acetonitrile, 50:50v/v solution. The mobile phase was filtered by using $0.45 \mu \mathrm{m}$ membrane filter and sonicated for $15 \mathrm{~min}$ prior to use. The mobile phase is also used as diluent.

\section{Preparation of standard stock solution}

Weighed accurately about $50 \mathrm{mg}$ of felodipine and transferred into $50 \mathrm{ml}$ volumetric flask and dissolved in $20 \mathrm{ml}$ of diluent. The final volume made up to the mark with diluent to get $1000 \mu \mathrm{g} / \mathrm{ml}$ concentration. From the above stock solution $(1000 \mu \mathrm{g} / \mathrm{ml}) 1 \mathrm{ml}$ was pipetted out and transferred into a $10 \mathrm{ml}$ clean and dry volumetric flask and diluted with solvent to get $100 \mu \mathrm{g} / \mathrm{ml}$ solution.

\section{Selection of wavelength}

From the stock solution $(100 \mu \mathrm{g} / \mathrm{ml})$. Further dilutions were made to get $10 \mu \mathrm{g} / \mathrm{ml}$ solution was scanned in UV-visible spectrophotometer in the range of $200-400 \mathrm{~nm}$, where the mixture of methanol $(50 \%)$ and acetonitrile $(50 \%)$ was used as a blank. The wavelength of maximum absorbance $\left(\lambda_{\max }\right)$ of felodipine was found at $230 \mathrm{~nm}$. The spectrum was shown in fig. 2 . 


\section{Preparation of sample solution for assay}

Twenty tablets of felodipine were weighed and the average weight was calculated. Tablets were finely powdered and the weight equivalent to $50 \mathrm{mg}(1.57 \mathrm{~g})$ was transferred into a $50 \mathrm{ml}$ volumetric flask $25 \mathrm{ml}$ of diluent was added and sonicated for $20 \mathrm{~min}$. The final volume was made up to the mark with diluent to get $1000 \mu \mathrm{g} / \mathrm{ml}$ solution. The above solution was filtered by using Whatman filter paper 42 . From the above solution $(1000 \mu \mathrm{g} / \mathrm{ml}), 1 \mathrm{ml}$ was transferred into $10 \mathrm{ml}$ volumetric flask and made up to the mark with diluent to get $100 \mu \mathrm{g} / \mathrm{ml}$ solution. Further dilution was made by pipetting out $1 \mathrm{ml}$ of $100 \mu \mathrm{g} / \mathrm{ml}$ solution into $10 \mathrm{ml}$ volumetric flask and made up to the mark with diluent to get $10 \mu \mathrm{g} / \mathrm{ml}$ solution. This solution was injected under chromatographic conditions and the peak area was calculated.

\section{Method development}

The HPLC procedure optimized with a view to developing a method for Assay. The column used for separation of analyte was phenomenex $\mathrm{C}_{18}$ column $(150 \mathrm{~mm} \times 4.6 \mathrm{~mm} 5 \mu \mathrm{m})$ using isocratic elution with methanol and acetonitrile as mobile phase (50:50). The sample was injected through ryanodine injector mode. The data was acquired, stored and analyzed in spinchrome software. The flow rate of mobile was $1.0 \mathrm{ml} / \mathrm{min}$ at room temperature. The retention time of both standard and sample felodipine was 3.140 min. The peak shape of felodipine was found to be symmetrical.

\section{Validation of the developed method}

The developed method was validated as per ICH guidelines for the following parameters.

\section{Linearity}

The linearity of a method is its ability to obtain test results that are directly proportional to the sample concentration over a given range. The linearity was performed in the concentration range of 5 to $25 \mu \mathrm{g} / \mathrm{ml}(5,10,15,20$, and 25). Then the five standard solutions of felodipine were injected into HPLC system at $230 \mathrm{~nm}$ by using diluent. The peak area and concentration were plotted to get a standard calibration curve were shown in fig. 3 .

\section{Precision}

The closeness of agreement between a series of measurements. Multiple sampling of homogeneous samples under a prescribed condition. The precision of the method was demonstrated by method precision, system precision, intraday precision, interday precision.

\section{System precision}

The system precision was performed by injecting six replicate injections of the standard solution into HPLC system. The peak area and RSD were calculated, were found to be not more than $2 \%$.

\section{Method precision}

The method precision performed by preparing six replicate sample preparations as per testing procedure and injected into HPLC system. The peak area and RSD were calculated, were found to be not more than $2 \%$.

\section{Intraday precision}

Intraday precision performed by preparing six replicate sample preparations as per testing procedure and injected into HPLC system. The peak area and RSD were calculated were found to be not more than $2 \%$.

\section{Interday precision}

Interday precision performed by preparing six replicate sample preparations as per testing procedure and injected into HPLC system.

\section{Accuracy}

The accuracy of an analytical method is the closeness of results obtained by that method to the true value for the sample. It is expressed as recovery (\%) and determined by the standard addition method. Samples were spiked with $80 \%, 100 \%$, and $120 \%$ of the standard and analyzed. The experiment performed in triplicate. Recovery (\%) and RSD (\%) were calculated for each concentration.

\section{Limit of detection (LOD)}

The detection limit of an individual analytical procedure is the lowest amount of analyte in a sample which can be detected but not necessarily quantified as an exact value. The detection limit (LOD) may be expressed as

$\mathrm{LOD}=3.3 \sigma / \mathrm{S}$

Where,

$\sigma=$ the standard deviation of the response

$\mathrm{S}=$ the slope of the calibration curve

\section{Limit of quantification (LOQ)}

LOQ is defined as the lowest concentration of the substance (analyte) in a sample that can be estimated quantitatively with acceptable precision, accuracy and reliability by a given method under stated experimental conditions. Quantification limit (LOQ) may be expressed as

$\mathrm{LOQ}=10 \mathrm{\sigma} / \mathrm{S}$

Where,

$\sigma=$ the standard deviation of the response

$\mathrm{S}=$ the slope of the calibration curve

\section{Robustness}

The robustness of an analytical method is a measure of its capacity to remain unaffected by small but deliberate variations in method parameters and provides an indication of its reliability during normal usage. It is concluded that the method is robust as it is found that the \%RSD is less than 2 . The results are shown in table 3 .

\section{Ruggedness}

Ruggedness is defined as the reproducibility of results when the method is performed under actual use conditions. This includes different analysts, laboratories, columns, instruments, the source of reagents, chemicals, solvents etc. Method ruggedness may not be known when a method is first developed, but insight is obtained during subsequent use of that method. The results are shown in table 4.

\section{Protein binding studies}

\section{Calibration curve}

The calibration curve was performed in the concentration range of 10 to $60 \mu \mathrm{g} / \mathrm{ml}$. Then the six standard solutions of felodipine were injected into HPLC system at $230 \mathrm{~nm}$ by using diluent. The peak area and concentration were plotted to get a standard calibration curve was shown in fig. 6.

\section{Preparation of bovine serum albumin}

Bovine serum albumin solution was prepared by dissolving the 300 $\mathrm{mg}$ of bovine serum albumin in $25 \mathrm{ml}$ of distilled water.

\section{Preparation of stock solution}

Weighed accurately about $50 \mathrm{mg}$ of felodipine was transferred into clean and dried $50 \mathrm{ml}$ volumetric flask. To that $25 \mathrm{ml}$ of diluent was added and sonicated for $5 \mathrm{~min}$ and the final volume was made up to the mark with diluent to obtain $1000 \mu \mathrm{g} / \mathrm{ml}$. From the above solution, $100 \mu \mathrm{g} / \mathrm{ml}$ concentration was prepared by transferring $1 \mathrm{ml}$ into $10 \mathrm{ml}$ volumetric flask and made up to the mark with diluent.

\section{Preparation of semi permeable membrane}

An egg shell was kept in concentrated HCL solution for about five minutes. The outer layer gets dissolved leaving membrane. The membrane was removed and washed with distilled water. 


\section{Procedure}

Both sides open ended cylinder was taken and semi permeable membrane was tied to one end. $20 \mathrm{ml}$ of bovine serum albumin and $20 \mathrm{ml}$ of $100 \mu \mathrm{g} / \mathrm{ml}$ felodipine solution was placed inside the semi permeable membrane. The cylinder was kept inside the beaker containing mobile phase. $5 \mathrm{ml}$ of solution was collected at different intervals $(10-60 \mathrm{~min})$ from the beaker and the same volume was replaced with mobile phase to maintain sink conditions. Then the solution was injected into HPLC system. From the chromatogram peak area was noted and percentage drug release was calculated. Results are shown in table 5 .

\section{RESULTS AND DISCUSSION}

The current RP-HPLC technique is most accurate, reliable and precise method of analysis for the quantitative estimation of felodipine in bulk drugs and its pharmaceutical dosage form. The current method system suitability was accounted by measuring tailing factor, plate count for the peak of felodipine from standard solution and percentage RSD of the area for the peak of felodipine from six replicate injections of standard solution. The obtained values are 0.9 as tailing factor (should not be more than 2.0), 15500 as plate count (should not be less than 2000), and percentage RSD of the area as 0.5 (should not be not more than 2.0). The typical felodipine retention time in current developed method was about 3.140. All Variations resulted with the very good percentage RSD of assay i.e. less than $2.0 \%$.

\section{Linearity and range}

The calibration curve showed good linearity in the range of 5$25 \mu \mathrm{g} / \mathrm{ml}$ for felodipine API with correlation coefficient $\left(\mathrm{R}^{2}\right)$ value of 0.994 (fig. 1). A typical calibration curve has the regression equation $y=149.9+153.2$ for felodipine.

\section{Precision}

\section{Method precision}

Method precision was determined by performing sample under the test concentration showed \% RSD less than 2 concerning \% assay of the drug which indicate that the method developed is method precise by the test of repeatability and hence can be understood that the method gives consistently reproducible results shown in table 4 .

\section{System precision}

Six consecutive injections of the sample at working concentration showed \% RSD less than 2 concerning \% assay of the drug which indicates that the method developed is system precise by the standard of repeatability and hence can be understood that the method gives consistently reproducible results shown in table 4 .

\section{Intraday precision}

Intraday precision studies were performed by injecting a standard solution of $10 \mu \mathrm{g} / \mathrm{ml}$ at several intervals i.e., 1,3 and $5 \mathrm{~h}$ within a day and the relative Standard deviation was calculated. The results are shown in table 4.

\section{Interday precision}

The Interday precision of the proposed method was determined by analysing the corresponding responses on different days for 10 $\mu \mathrm{g} / \mathrm{ml}$ felodipine standard solution. The relative standard deviation was calculated. The results are shown in table 4.

\section{Limit of detection and limit of quantification}

Method sensitivity was estimated in terms of limit detection and limit of quantification by using formula. The detection of LOD and LOQ is based on the standard response of felodipine by plotting separate calibration curve.

$$
\text { LOD }=3.3 \times 150.123 / 165.7=2.9 \mu \mathrm{g} / \mathrm{ml}
$$$$
\mathrm{LOQ}=10 \times 150.123 / 165.7=9.0 \mu \mathrm{g} / \mathrm{ml}
$$

Where $s$ is the slope of calibration plot, $\sigma$ is standard deviation calculated using values of $y$-intercept of the regression equation.

\section{Accuracy}

The mean recovery of the method determined by standard addition method and found to be $100 \%$. The values of $\%$ recovery and \% RSD, listed in table 3 indicate that the method is accurate.

\section{Robustness}

The robustness of an analytical procedure is a measure of its capacity to remain unaffected by small, but deliberate variations in method parameters. For the proposed method robustness was checked by making small deliberate changes in wavelength i. e, \pm 0.2 $\mathrm{nm}$. After making these small changes showed thevery slight difference in peak area for estimation of felodipine. The values are given in table 2 point out method is robust.

\section{Ruggedness}

It is the reproducibility of test results under operating condition from analyst to analyst, column to column variations. The ruggedness of the method was performed by comparing the results between two analysts, columns in the same laboratory and results given table 3 .

\section{Protein binding studies}

Protein binding studies were performed based on the calibration curve (concentration $\mathrm{v}_{\mathrm{s}}$ peak area) and then calculating the percentage drug release.<smiles>CCOC(=O)C1=C(C)NC(C)=C(C(=O)OC)C1c1cccc(Cl)c1Cl</smiles>

Fig. 1: Structure of felodipine.

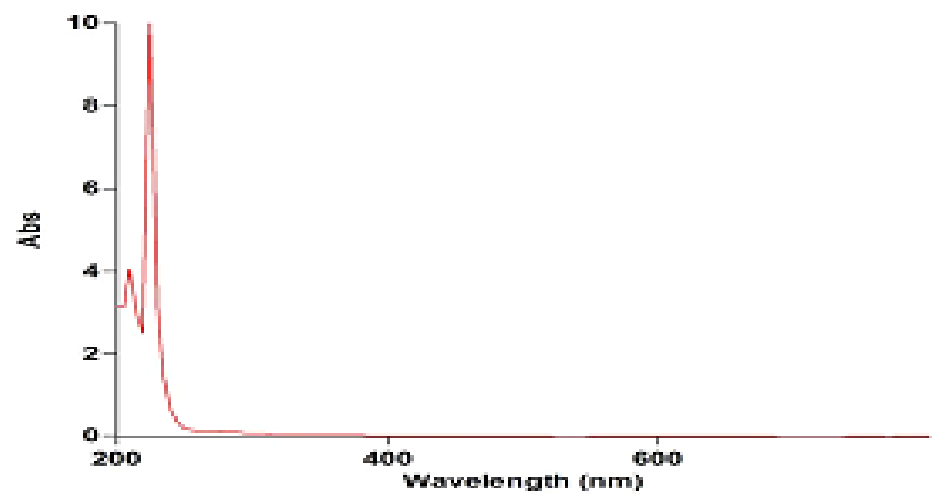

Fig. 2: UV spectrum of felodipine 


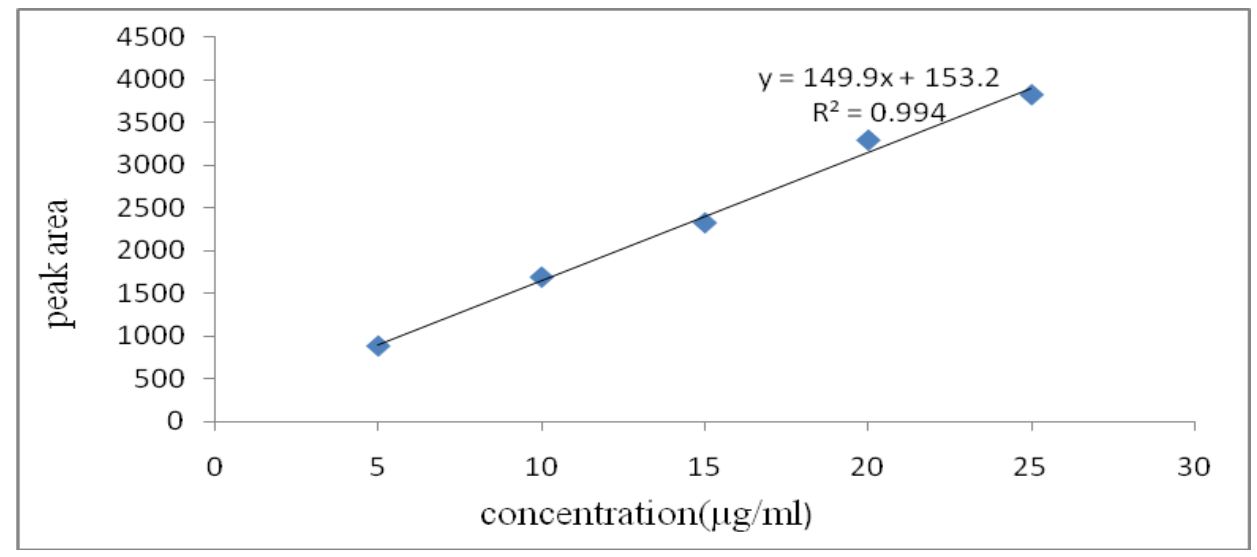

Fig. 3: Calibration curves of felodipine

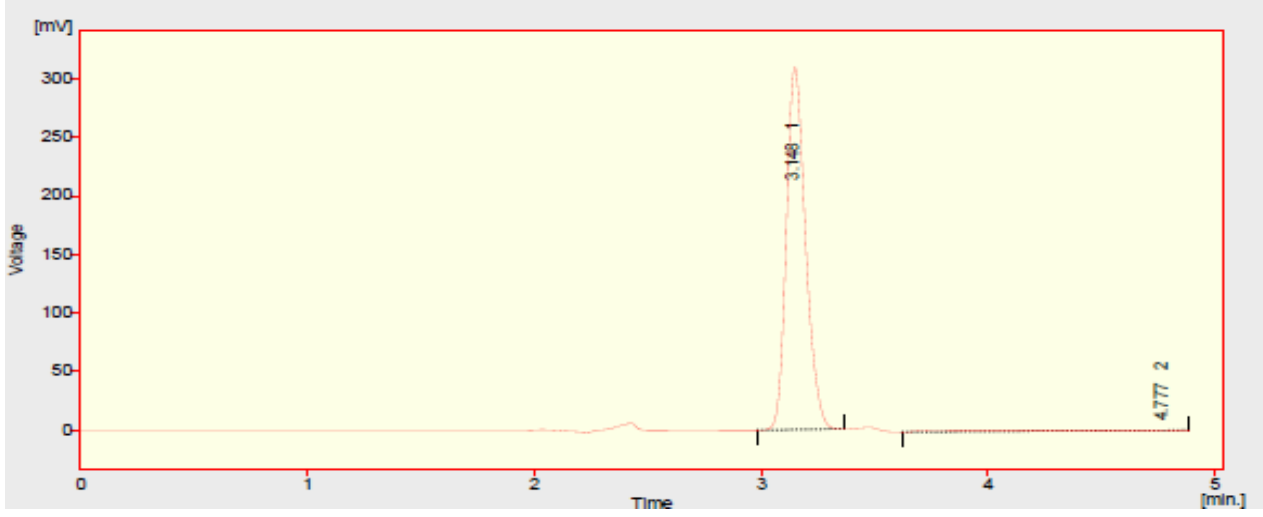

Fig. 4: Typical chromatogram of standard felodipine

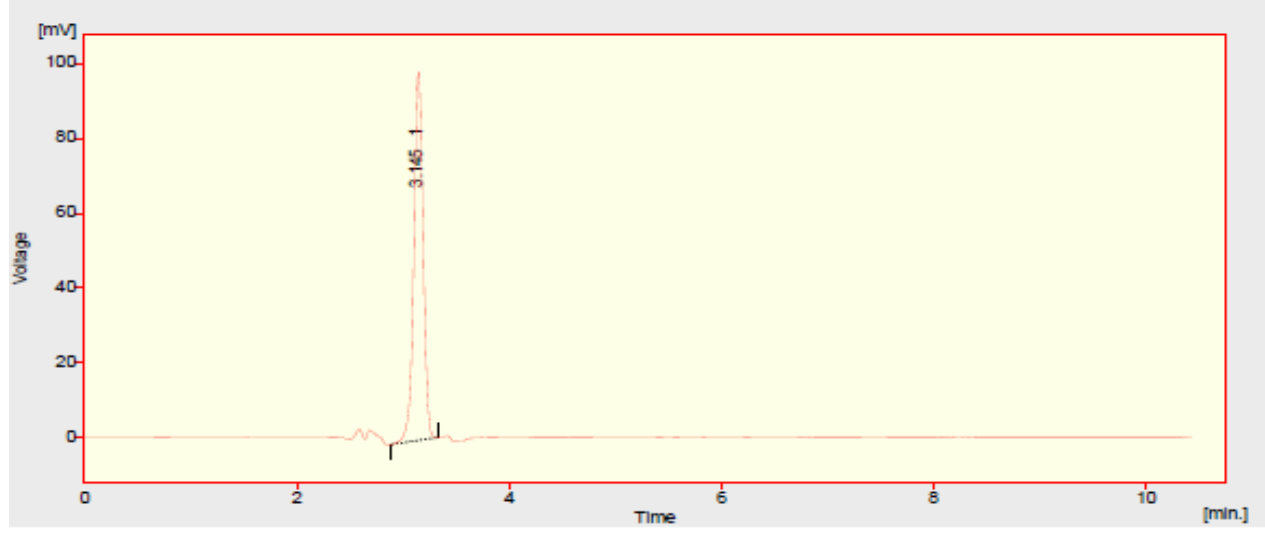

Fig. 5: Typical chromatogram of sample felodipine

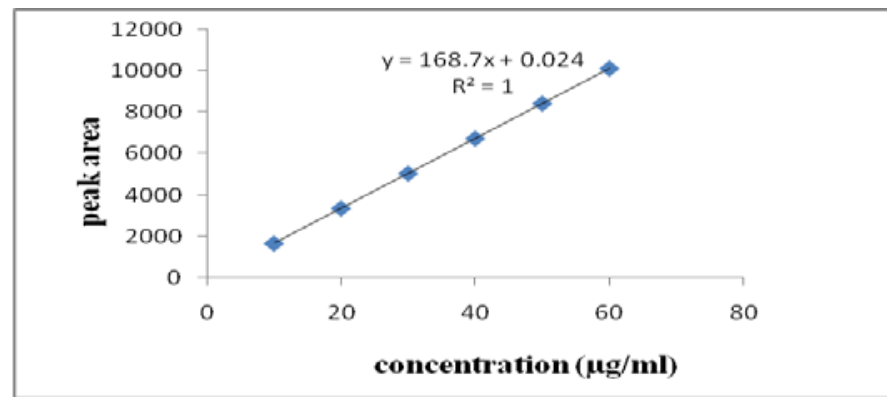

Fig. 6: Standard graph of felodipine 


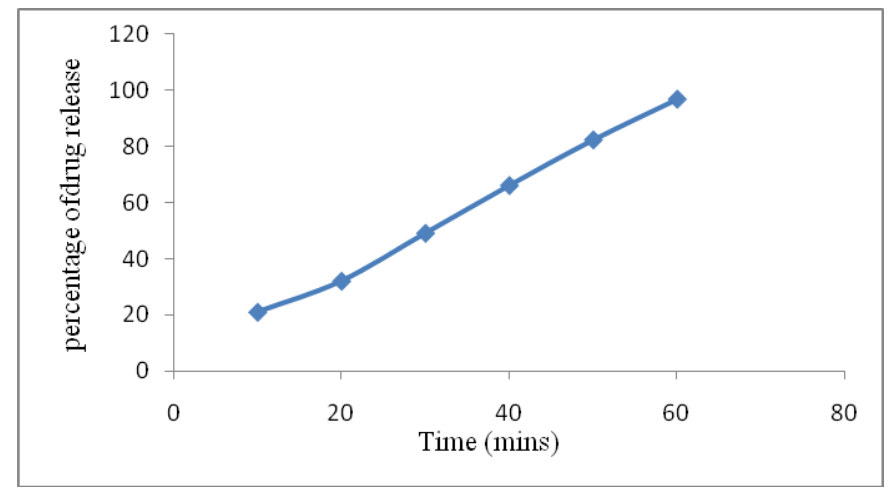

Fig. 7: Drug release kinetics of felodipine

Table 1: Accuracy of felodipine

\begin{tabular}{|c|c|c|c|c|c|c|}
\hline \multirow[t]{2}{*}{ S. No. } & \multirow[t]{2}{*}{ Recovery level } & \multirow{2}{*}{$\begin{array}{l}\text { Amount added } \\
(\mu \mathrm{g} / \mathrm{ml}) \\
10\end{array}$} & \multirow{2}{*}{$\begin{array}{l}\text { Amount spiked } \\
(\mu \mathrm{g} / \mathrm{ml})\end{array}$} & \multirow{2}{*}{$\begin{array}{l}\text { \% recovery } \\
99.75\end{array}$} & \multicolumn{2}{|c|}{ Statistical analysis of \% recovery } \\
\hline & & & & & Mean & 99.81 \\
\hline \multirow[t]{3}{*}{1.} & $80 \%$ & 10 & 8 & 99.3 & Std. dev & 0.533 \\
\hline & & 10 & 8 & 100.4 & $\% \mathrm{RSD}$ & 0.554 \\
\hline & & 10 & 10 & 100.35 & Mean & 99.91 \\
\hline \multirow[t]{3}{*}{2.} & $100 \%$ & 10 & 10 & 99.9 & Std. dev & 0.425 \\
\hline & & 10 & 10 & 99.5 & $\%$ RSD & 0.425 \\
\hline & & 10 & 12 & 99.81 & Mean & 100.006 \\
\hline \multirow[t]{2}{*}{3.} & $120 \%$ & 10 & 12 & 100.06 & Std. dev & 0.176 \\
\hline & & 10 & 12 & 100.15 & $\%$ RSD & 0.175 \\
\hline
\end{tabular}

Table 2: Robustness of felodipine

\begin{tabular}{llll}
\hline S. No. & Concentration $(\boldsymbol{\mu g} / \mathbf{m l})$ & Peak area at different wavelengths & $\mathbf{2 3 2} \mathbf{n m}$ \\
\cline { 3 - 4 } & & $\mathbf{2 2 8} \mathbf{~ n m}$ & 3595.658 \\
1. & 10 & 3321.038 & 3586.846 \\
2. & & 3283.931 & 3635.130 \\
3. & 3318.351 & Mean $=3605.878$ \\
& & Mean $=3341.106$ & $\mathrm{SD}=50.437$ \\
& & $\mathrm{SD}=50.437$ & $\% \mathrm{RSD}=1.509$ \\
\hline
\end{tabular}

Table 3: Ruggedness of felodipine

\begin{tabular}{|c|c|c|c|c|c|}
\hline \multirow[t]{2}{*}{ S. No. } & \multirow[t]{2}{*}{ concentration $(\mu \mathrm{g} / \mathrm{ml})$} & \multicolumn{2}{|c|}{ Peak area at different analysts } & \multicolumn{2}{|c|}{ Peak area of different columns } \\
\hline & & Analyst-1 & Analyst-2 & Column-1 & Column-2 \\
\hline 1. & 10 & 1270.200 & 1266.450 & 1424.208 & 1266.450 \\
\hline 2. & & 1260.458 & 1284.904 & 1454.03 & 1284.904 \\
\hline \multirow[t]{4}{*}{3.} & & 1266.449 & 1281.802 & 1339.320 & 1281.802 \\
\hline & & Mean $=1275.702$ & Mean $=1285.012$ & Mean $=1439.10$ & Mean $=1285.012$ \\
\hline & & $\mathrm{SD}=6.949$ & $\mathrm{SD}=9.83$ & $\mathrm{SD}=21.075$ & $\mathrm{SD}=9.8$ \\
\hline & & $\% \mathrm{RSD}=0.5$ & $\% \mathrm{RSD}=0.7$ & $\% \mathrm{RSD}=1.4$ & $\% \mathrm{RSD}=0.7$ \\
\hline
\end{tabular}

Table 4: Validation and system suitability parameters

\begin{tabular}{ll}
\hline Parameters (units) & Results \\
\hline Linearity range $(\mu \mathrm{g} / \mathrm{ml})$ & $5-25$ \\
Correlation coefficient & 0.994 \\
Slope & 149.9 \\
Intercept & 153.2 \\
Recovery $(\%)$ & 100 \\
Assay & $100 \%$ \\
System precision & 1.3 \\
Method precision & 1.4 \\
Intraday precision & 0.7 \\
Interday precision & \\
Robust & 0.9 \\
Retention time & \\
Tailing factor & Robust \\
\hline
\end{tabular}


Table 5: Drug in vitro protein binding study data

\begin{tabular}{lll}
\hline S. No. & Time (min) & \% drug release \\
\hline 1. & 10 & 21.038 \\
2. & 20 & 32.076 \\
3. & 30 & 49.114. \\
4. & 40 & 66.123 \\
5. & 50 & 82.345 \\
6. & 60 & 96.806 \\
\hline
\end{tabular}

\section{CONCLUSION}

There is no specific and short retention time analytical method reported in literature for felodipine. The developed method gaveadequate resolution with a short analysis time. The method was validated as per ICH guidelines. All the validation parameters were found to be well within the acceptance criteria. We conclude that the method was accurate, reproducible, repeatable, linear, precise, and reliable. This method is used to perform protein binding study of felodipine with egg membrane and the total drug release after 60 min was found to be $96.8 \%$ and it was good agreement with reported pharmacokinetic data and drug release kinetics.

Hence the developed methodis used for routine analysis of felodipine in bulk and pharmaceutical formulations in quality control and pharmacokinetic studies.

\section{ACKNOWLEDGEMENT}

Authors are thankful to Dr. Mohan Babu, chairmen, Sree Vidyanikethan College of Pharmacy Sree Sainath Nagar, Chandragiri (Mandal), Tirupati, Chittoor (Dist), A. P. for providing the necessary facilities to carry out this research work.

\section{CONFLICT OF INTERESTS}

The authors declare no conflict of interest

\section{REFERENCES}

1. The merckindex: an encyclopedia of chemicals, drugs and biological, merck research laboratories, merck; 2001.

2. Tripathi KD. Essentials of medical pharmacology. $6^{\text {th }}$ ed. Jaypee brothers medical publishers (p) Ltd, New Delhi; 2000. p. 181-2.
3. Validation of analytical procedures: text and methodology, in: international conference on harmonization (ICH), Q2A, Q2B(R); 2005.

4. Dhalechaitali, Joshisuhas, Shubhangi. Development and validation RP-HPLC method for analysis felodipine in bulk and pharmaceutical dosage form. Int Res J Pharm 2014;5:770-2.

5. Sangeetha dhanaraj, Manoj Kumar Vadlamudi. Stability indicating method for the determination of related substances in felodipine solid dosage form and in the drug substance by RP-HPLC". J Bioequivalence Bioavailability 2016; 851;153-66.

6. Arsul VA. Analytical method development and validation of felodipine by uv and rp-hplc method. Pharm Chem 2016;6:181-5.

7. Nataraj KS, S Sureshkumar. Method validation and estimation of felodipine in pure and capsule dosage form by RP-HPLC. J Pharm Res 2011;4:2822-3.

8. Liandong, Qiaofeng $\mathrm{Hu}, \mathrm{Na}$ Gao. A validated stability indicating stability HPLC method for determination of felodipine and its related substances. Int J Pharm Sci Res 2015;11:1-9.

9. Vaibhav M Thorat, Pawar SS, Pande VV, Arote SR, Musmade Deepak. Development and validation of UV spectrophotometric method for estimation of process related impurity in felodipine bulk and formulation. Scholars Res Library 2015;7:284-90.

10. Gandla, Kumaraswamy. Development and validation of stability indicating RP-HPLC method for simultaneous determination of enalapril maleate and felodipine in bulk and tablet dosage form. World J Pharm Res 2015;3:2087-100.

\section{How to cite this article}

- $\quad$ Swarna Vijitha, P Rajavel, K Udayasree. Protein binding study of felodipine using validated liquid chromatographic method. Int J Curr Pharm Res 2017;9(5):134-139. 